\title{
[委員会報告 $]$
}

\section{発㮂物海面埋立環境保全調査}

\section{STUDY ON ENVIRONMENTAL PRESERVATION FOR FINAL DISPOSAL OF SOLID WASTE IN SEA}

土木学会環境工学委員会 広域処分小委員会

\section{Environmental Engineering Committee Subcommittee on Regional Waste Disposal}

\section{1. はじめに}

平成 9〜11 年度の 3 ケ年において行った本委員会の調 查項目は, 埋立処分量最小化への対応から始まり, 広域 輸送，溶融処理による最終処分量の削減，リサイクル問 題, 処理場建設に際しての住民参加問題, 海面埋立処分 の際の環境保全, 埋立工法の高度化, 海面埋立跡地利用 に関する検討まで海面埋立に関する多くの課題について 取り組んでいる.

なお, 広域処分小委員会の委員, 及び幹事は次のとお りである.

委員長：花嶋正孝（福岡大学）, 副委員長 : 田中勝（国 立公衆衛生院), 幹事長 : 井上雄三（国立公衆衛生院）, 委員: 今岡務 (広島大学), 大西有三 (京都大学), 金谷 健 (滋賀県立大学), 川島尚 (川崎市), 河原長美 (岡山 大学), 北脇秀敏 (東洋大学), 杉山吉男 ((財) かなが わ廃棄物処理事業団), 田澤眞樹 (東京都), 古市徹 (北 海道大学), 山本和夫 (東京大学), 委員兼幹事 : 宮脇健 太郎 (福岡大学), 協力委員 : 山田規世（(株）建設技術 研究所). 所属は, 平成 12 年 3 月現在のものである.

\section{2. 埋立処分量最小化への対応}

\section{（1）埋立処分場の延命の必要性}

日本は，他国と比較して人口密度が高く，しかも都市 部に産業, 人口が集中している. 人口が集中する都市で は, 廃棄物の発生密度も高くなるが，その反面空間資源 は不足し, 廃㶳物を処理・処分する施設, 特に広大な敷 地を要する最終処分場の整備は年々困難になってきてい る. さらに, 最終処分場の建設は, 周辺環境への影響の 不安から住民の理解が得にくく, 施設の新設整備はほと
んど進まない状況となっている，産業廃棄物最終処分場 の新規許可件数は, 96 年度に 193 件, 97 年度に 129 件, 98 年度も 129 件と推移してきたが, 99 年度上半期は 9 件と激減している，処分場の確保は少ないながらも，中 間処理等による最終処分量の減量化もあって処分場の残 余年数は確保されてきたところである.しかしながら， 産業廃棄物処分場に関しては処分場新設の激減の影響も あり, 96 年末現在で 3.1 年分あった残余年数が 99 年 9 月現在でわずか 1.6 年分という厚生省の報告が出されて いる. わずか 2 年半でほぼ半減しており, 日本経済に悪 影響を及ぼしかねないほどの危機的状況にある。

埋立処分場を確保するにあたって, 内陸部では土地が 高度に利用され埋立に必要な用地がない場合は, 海面に 処分場を求めるしか方法が残されていない，湾岸はいろ いろな用途に使用され貴重な空間でもあり，長期的観点 から海域を適正に利用保全することを考えると，海に面 した自治体だけが海面を使うのではなく，個々の湾岸の 区域を超えて広域的観点から対応することが望まれる。 今後, 安定した経済成長や国民生活を維持するためには, 廃棄物の減量化，再資源化を促進し，埋立処分地の延命 を図ることが緊急な課題となっている.

\section{（2）埋立処分量最小化への地方自治体の選択}

多くの自治体では，埋立処分場の延命を図るため，可 燃物は全量焼却により減量することが基本となっている. 処理対象ごみの一部，欴芥類等の有機ごみを堆肥化した り，動物の飼料として利用する試みが行われている．特 に堆肥化では，発生源である家庭で行うコンポスト容器 等の家庭用ごみ処理機が減量に大きな役割を果たしてい る．また，資源ごみ，分別ごみとして紙，ガラス，金属 等を分別収集し，(1)資源化施設で更に選別再資源化を図 


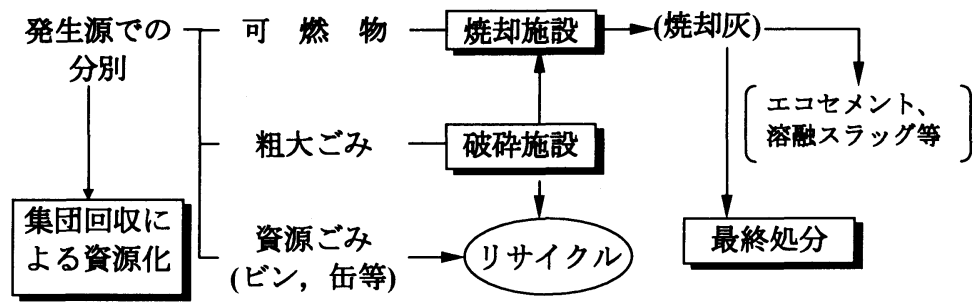

图一1 最終処分量を最小化才る廃棄物処理システム

表ー1 日本の 13 大都市のごみ処理の状況

\begin{tabular}{|c|c|c|c|c|c|c|c|c|c|c|}
\hline & \multirow{2}{*}{$\begin{array}{c}\text { 総排出量 } \\
(\text { 万 } \mathrm{t})\end{array}$} & \multicolumn{5}{|c|}{ 分別方法 } & \multirow{2}{*}{$\begin{array}{c}\text { 資源化率 } \\
(\%)\end{array}$} & \multirow{2}{*}{$\begin{array}{c}\text { 焼却率 } \\
(\%)\end{array}$} & \multirow{2}{*}{$\begin{array}{c}\text { 最終 } \\
\text { 処分率 } \\
(\%)\end{array}$} & \multirow{2}{*}{$\begin{array}{c}\text { 年間一人 } \\
\text { あたりの } \\
\text { 排出量 }(\mathrm{kg})\end{array}$} \\
\hline & & 混合 & 可燃 & 不燃 & 資源 & 粗大 & & & & \\
\hline 札幌市 & 92.8 & - & 0 & 0 & 0 & 0 & 5.5 & 73.1 & 33.5 & 515.4 \\
\hline 仙台市 & 46.5 & 0 & - & - & 0 & 0 & 6.3 & 90.9 & 16.2 & 466.1 \\
\hline 千葉市 & 37.0 & - & 0 & 0 & 0 & 0 & 13.0 & 85.1 & 14.7 & 424.7 \\
\hline 東京特別区部* & 396.6 & - & 0 & 0 & 0 & 0 & 8.2 & 85.1 & 22.7 & 489.8 \\
\hline 横浜市 & 158.6 & $\mathrm{O}$ & - & - & 0 & 0 & 2.8 & 96.1 & 20.2 & 470.7 \\
\hline 川崎市* & 56.8 & 0 & - & - & 0 & 0 & 14.3 & 85.5 & 14.1 & 461.7 \\
\hline 名古屋市* & 110.2 & - & 0 & 0 & 0 & 0 & 7.0 & 80.1 & 25.4 & 511.0 \\
\hline 京都市 & 79.7 & $\mathrm{O}$ & - & - & 0 & 0 & 2.7 & 91.3 & 21.2 & 545.6 \\
\hline 大阪市 & 187.1 & 0 & - & - & 0 & 0 & 1.5 & 91.3 & 28.2 & 722.4 \\
\hline 神戸市 & 87.7 & 0 & - & - & 0 & 0 & 0.2 & 80.6 & 19.3 & 615.2 \\
\hline 広島市* & 43.9 & - & 0 & 0 & 0 & 0 & 11.3 & 72.6 & 25.1 & 391.8 \\
\hline 北九州市 & 50.4 & 0 & - & - & 0 & 0 & 2.4 & 94.4 & 20.8 & 496.6 \\
\hline 福岡市 & 73.2 & - & 0 & 0 & - & 0 & 3.1 & 87.9 & 21.2 & 550.5 \\
\hline 全国 & 5043.9 & & & & & & 5.9 & 76.9 & 26.0 & 401.0 \\
\hline 東京都三多摩地区 & 132.0 & - & 0 & 0 & 0 & 0 & 17.4 & 79.7 & 12.4 & 346.8 \\
\hline 東京都三多摩地区 ${ }^{*}$ & 141.5 & - & 0 & 0 & $\mathrm{O}$ & 0 & 22.8 & 74.4 & 11.6 & 371.8 \\
\hline
\end{tabular}

（注 1）全国は 1996 年度, 神戸市は 1997 年度, それ以外は 1998 年度データ

（注 2）＊印は総排出量及び資源化量に集団回収を含む

（注 3）神戸市は家庭ごみ(生ゴミ, 紙布類等), 荒ごみ(家具, 電気製品, プラスチック, 金属, ガラス類等), 空き缶・ペットボ トル，事業系ごみという呼び名で分別収集している

（注 4） 資源化率＝資源化量 / 総排出量

焼却率二焼却量 $/$ 総排出量

最終処分率 $=$ 最終処分量 $/$ 総排出量

年間一人あたりの排出量＝総排出量 $/$ 人

る場合，(2)粗大ごみ（家電製品や家具類等の大型ごみ） を破砕し，素材別に有価物を選別，回収する場合がある. 各自治体では，図ー1 に示すようにこうした様々な手法 を組み合わせ, リサイクルを促進し最終処分量の最小化 が図られている，最近では，焼却灰の溶融スラグ化，エ コセメント化等の技術開発も進んでおり, 最終処分量最 小化への努力が続けられている。これらの技術や施策の 選択には, 今後の最終処分場確保の可能性や技術の成熟 度, 経済性が重要な評価項目となる。

\section{（3）埋立処分量の最小化に向けて}

リサイクルシステムや廃棄物処理システムの段階的改 善により処分場への負荷を抑制するとともに，物質循環 の上流に遡って, ものの生産・流通・消費という各段階
から，ごみの発生排出を抑制していくことが必要である. 自治体によっては処分場の確保が不可能なところもあり， これまで実施されてきた施策に加えて，規制的措置，経 済的手法等の様々な施策についても適宜導入を図り, 埋 立処分対象量の最小化を推進する必要性が高まっている.

一般廃棄物の処理及び最終処分の状況を見ると, ごみ 排出量に対する最終処分量の割合が，全国では 26.0\%（96 年度）であるが，三多摩では $12.4 \%$ （98 年度）と大幅な 減容化がなされている。ごみの再資源化と直接埋め立て の削減が効果を上げていると考えられ，新たな最終処分 場の確保が厳しい状況にある三多摩地域の取り組みがう かがえる. 全国 13 大都市のごみの資源化率等を表ー1に まとめたが，三多摩の資源化率は非常に高く，年間の一 人あたりのごみ排出量も他の都市と比較して少ない. 


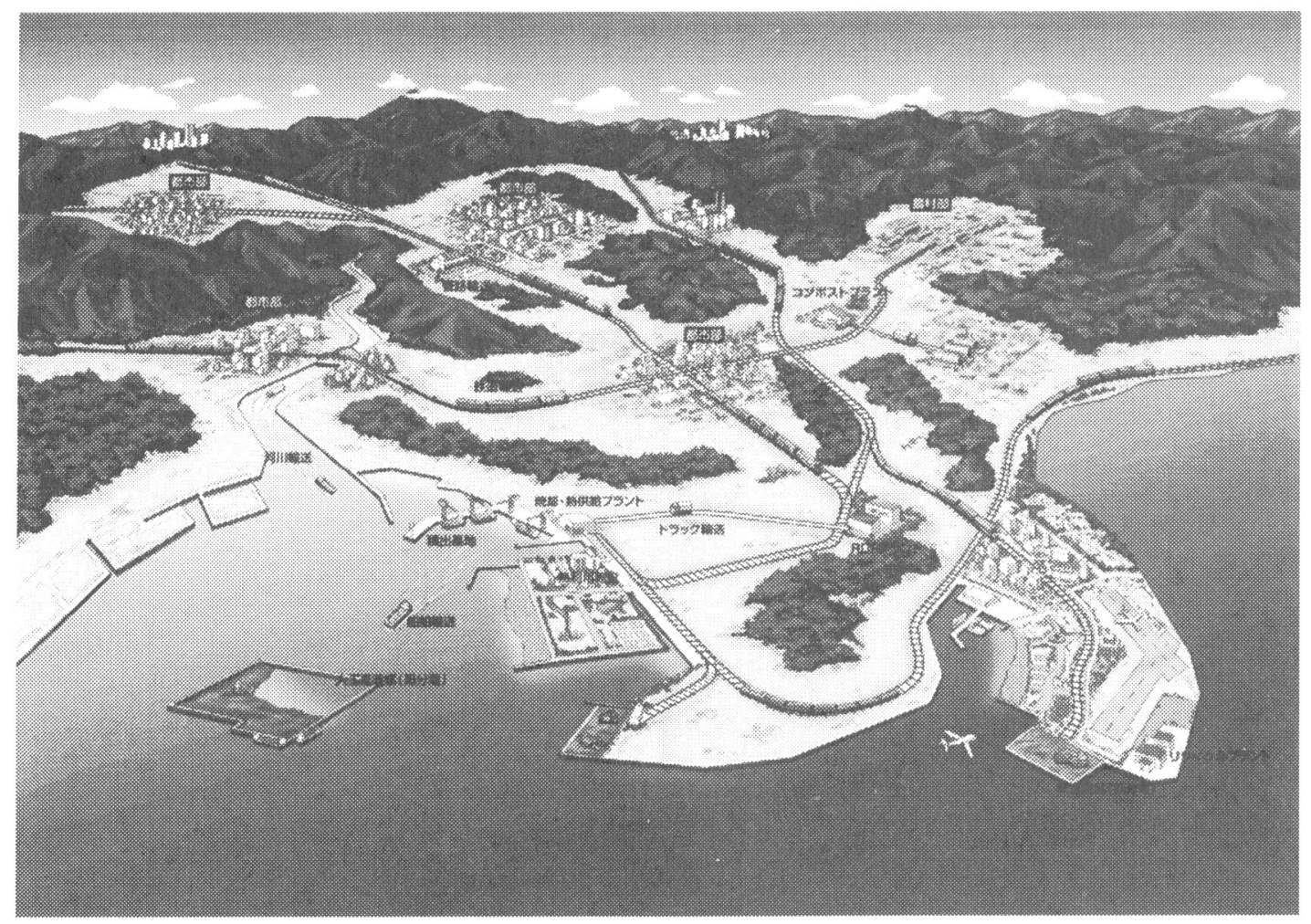

図一2 理想と小る広域輸送システム概念図

\section{3. 広域輸送と最終処分問題}

廃棄物処理には，解決すべきさまざまな問題がある。 例えば最終処分場の候補地選定の難しさ，迷惑施設とし ての住民感情の悪さ, 小規模焼却炉からの有害物の発生, リサイクルの採算性の悪さや回収された資源の市場性の 悪さ等枚挙にい上まがない.

こうした問題を解決するための一つの解決策がごみの 広域輸送である，処理・処分地が限定された場合にやっ かいな存在になる廃棄物も広域輸送することにより他の 地域で資源として利用できる可能性がある，例をあげれ ば寒冷地での大規模焼却炉による熱供給, 農地でのコン ポスト利用やセメント工場での RDF 利用, 海面処分場に おける土地の創造などである。また最近では容器包装リ サイクル法等により回収された資源を効率的に再生する ためには広域輸送が大きな役割を果たすと考えられる. このような背景のもと, 本項では広域輸送が循環型社会 の構築に寄与する点を検討した。

海面埋立処分場は, 従来都市部に近い内湾を埋立して 行われていたが，利用価值が高い内湾の面積を減じるよ り外洋を埋め, 多目的利用が行える土地と海岸線とを創 造する方が国土創造としての付加価值が高いと考えられ
る. 広域輸送と海面埋立, 国土創造というキーワードを 念頭に描いたものが図ー2（参考文献：廃棄物学会自主 研究グループ, 平成 9 年度廃棄物学会自主研究, 廃棄物 の広域輸送に関する研究）である。図は鉄道輸送等の広 域輸送手段を中心に据えて循環型社会のあるべき姿を描 いたものである。

\section{4. 都市ごみ溶解スラグの道路路盤材へのリサイ クル可能性の需要面からの検討}

最終処分場の残余年数は短く, 最終処分量の削減が課 題となっている.そのための方法の一つとして一般廃棄 物（焼却灰）溶融技術は, ごみ排出量の抑制, 資源の再 利用と共に大きな効果を期待されている。そこで東京都 などすでに焼却灰溶融炉を導入している自治体, 川崎市 などの今後焼却灰溶融炉の導入を検討している自治体な どが「焼却灰有効利用マニュアル」などを策定している. また(財)廃棄物研究財団をはじめ, メ一カ一, 自治体レ ベルでは, 暁却灰溶融スラグの道路路盤材への試験施工 も行われている. しかし, 都市ごみ溶融スラグの道路路 盤材へのリサイクル可能性の需給面からの検討はあまり されておらず, 本研究ではこの点について検討した。 
表ー2 リサイクルによる

\begin{tabular}{|c|c|c|c|c|c|c|}
\hline \multirow{2}{*}{$=$ 量 } & \multirow{2}{*}{ こみれ } & \multirow{2}{*}{$\begin{array}{l}\text { 等生竞 } \\
(\mathrm{kg})\end{array}$} & \multirow{2}{*}{ 主たる然生酒 } & \multirow{2}{*}{ 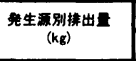 } & \multicolumn{2}{|c|}{ リサイクル事(\$) } \\
\hline & & & & & 现 況 & t \\
\hline & コンクリート、モルタルくず & 39,320 & 基礎工事 & 39,320 & 60 & 90 \\
\hline \multirow{2}{*}{2} & $T$ & 10,035 & むく材 & 6,690 & 30 & 90 \\
\hline & & & 防腐、防錘処理、塗装、合板 等 & 3.345 & & \\
\hline \multirow{2}{*}{3} & 金到 & & アルミサッシ & 97 & 100 & 100 \\
\hline & 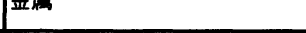 & ${ }^{140}$ & その他金虏 & 49 & 0 & 0 \\
\hline 4 & 石衰ボード & 2,818 & 壁と天井 & 2,818 & 0 & 85 \\
\hline \multirow{3}{*}{5} & & & 量 & 390 & & \\
\hline & 燃えるもの & 586 & ビニールクロス & 142 & 0 & 100 \\
\hline & & & その他 & 54 & & \\
\hline \multirow{2}{*}{6} & 怢えたい未田 & & 屋根のカラーベスト & 2.030 & 0 & $\underline{0}$ \\
\hline & |然えないもの & $3.0 / 4$ & その他 & 3.044 & 0 & 0 \\
\hline 7 & 電線 & 66 & & 66 & 0 & 0 \\
\hline \multirow{2}{*}{8} & ガラス、陶磁器 & 523 & ガラス & 418 & 0 & \\
\hline & 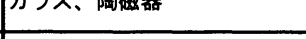 & 323 & 街生器具等 & 105 & 0 & \\
\hline \multirow{3}{*}{9} & & & 給排水設備 & 120 & & \\
\hline & 塩ビ管 & 182 & 找 & 48 & 0 & 0 \\
\hline & & & 換気厥のパ イ゚ & 14 & & \\
\hline \multirow{7}{*}{10} & \multirow{7}{*}{ その他 } & \multirow{7}{*}{811} & システムキッチン & 340 & \multirow{7}{*}{0} & \\
\hline & & & 給排水設備 浄化槽(単独7人) & 70 & & \\
\hline & & & 街生器具 & 152 & & \\
\hline & & & 被得鋼管 & 99 & & 0 \\
\hline & & & 給湯器、タンク & 62 & & \\
\hline & & & 照明器具、コンセント類 & 75 & & \\
\hline & & & その他 & 13 & & \\
\hline
\end{tabular}

(1)コンクリート、モルタルくず：マテリアルリサイクルを前提とする。

(2)木くず

$\therefore$ 埋立処分量 =発生量-リサイクル量( (発生量 $\times 0.9)$

: むく材、防腐処理材ともにリサイクル率は同じと仮定。

むく材はマテリアルリサイクル、防腐処理材はサーマルリサイクルとする。

$\therefore$ むく材の埋立処分量 =発生量-リサイクル量 (=発生量 $\times 0.9)$

(3)金属

防度処理材の埋立処分量=発生量一リサイクル量 (発生量 $\times 0.9)+$ 焼却灰（リサイクル量の5％)

: アルミサッシのみをリサイクルの対象とする。

$\therefore$ 埋立処分冝 =発生量-リサイクル是 (=発生量)

本研究の意義は, 第一に, 都市ごみ（焼却灰）を溶融 スラグ化して道路路盤材にリサイクルできれば，最終処 分量が大幅削减でき，処分場問題の解決につながること であり，第二に，道路路盤材として使用されている天然 材（上層路盤材としての $\mathrm{M}-30$, 下層路盤材としての $\mathrm{C}$ -30，40 等）の使用抑制に貢献でき，資源節約・自然破 壊抑制につながることである.

そこでこの需給面について，日本全体，地方レベル（近 畿, 関東など), 都道府県レベルで検討した．スラグの 需要面としては, 道路路盤材として現在使用されている クラッシャラン（日本全体で年間約 1 億 2,000 万トン） の $25 \%$ 想定した．スラグの供給面としては，ごみ焼却 量の $15 \%$ （日本全体で年間約 550 万トン）が溶融スラグ 量に対応すると想定した。その結果，次のことがわかっ た.

(1)日本全体の場合，[クラッシャランの需要量の $25 \%$ $>$ 焼却灰溶融スラグ発生量]であり, スラグの受入先と して十分な需要量である. 地方レベルでも, 同様である.

(2)しかし都道府県レベルになると, [クラッシャランの 需要量の $25 \%<$ 焼却灰溶融スラグ発生量]となる都道
府県がある。

このように, マクロ（日本全体, 地方レベル）では十 分な需要量であっても, ミクロ（都道府県以下のレベル） では必ずしも十分な需要量が存在しない場合がありうる.

次に市町村レベルでの需給バランスの検討を行った. 具体的には滋賀県内 7 市を対象として, 各市町村から発 生しうる都市ごみ由来の溶融スラグ量と, 各市の市道で の道路路盤材使用量（特に天然材使用量に着目）とを， それぞれ推計し, 比較した. その結果, 滋賀県 7 市につ いて，都市ごみを全量溶融スラグした場合の溶融スラグ 発生量を, 市道の道路によって異なるが, スラグ混合率が 10\%から 26\%以上であれば，溶融スラグの全量を受け入 れることが受給バランス的には可能であることがわかった。

なお今後, 都市ごみ溶融スラグの道路路盤材へのリサ イクルを各自治体が本格的に検討するならば, 各自治体 での道路工事での路盤材使用量を, 工事種類別・使用材 別にデータベース化し, 自治体清掃部局が把握する必要 がある．また，建設系廃棄物（副産物）のリサイクル促 進に伴い, 道路路盤材中の再生材の比率はより高まって いくことが予想される. その場合, 「天然材への溶融ス 


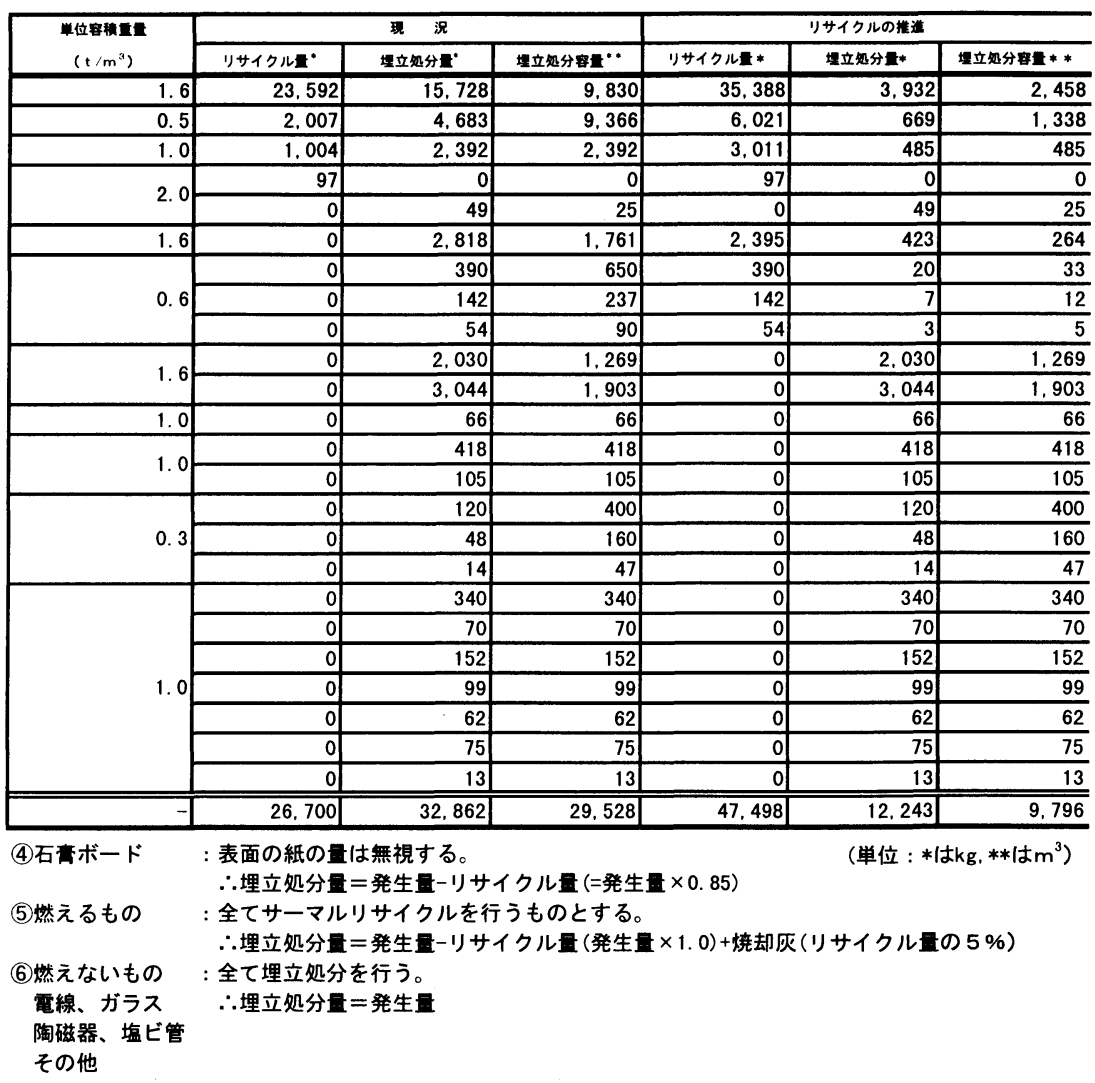

ラグの混合という形での溶融スラグリサイクル」は，長 期的には困難となる. 天然材の使用量自体が減少するか らである. 都市ごみ発生量自体の減量化, 天然材への混 合可能率の増加，そして最後の砦として一定規模の最終 処分場の確保が必要であろう.

\section{5. 在来エ法による建築物のリサイクルの方策}

産業廃棄物の種類別排出量の約 $15 \%$ を占める建設廃材 のリサイクルによる効果(减量・減容)を検討した.

検討の対象として, 建設廃棄物の中で不法投棄の主要 因として指摘される在来工法による木造住宅を取り上げ， 設計図面より投入材料を明確にし, 解体時における廃棄 物の発生場所・量を検討するとともに，各材料ごとに適 切なリサイクルの方法を検討し，その効果(減量・減容化) を確認した。

\section{（1）検討対象家屋}

検討対象とした家屋は, 築後約 10 年, 延べ床面積約 40 坪 $\left(132 \mathrm{~m}^{2}\right)$ の実在する標準的な住宅であり, 設計図面 より投入材料の内容と, 解体時における廃棄物の発生箇
所及び量を確認した。 その結果, 基礎工事によるコンク リート，モルタルくずを最大に，一戸あたり，約 $59,561 \mathrm{~kg}$ の廃棄物が発生することが分かった。

\section{（2）リサイクルの方策の検討，}

各投入材料ごとに，(1)現状のリサイクル技術の動向， (2)各投入材料の性状，(3)リサイクル時における各投入材 料に含まれる有害物質の举動, 及び(4)各省庁の動向等に 着目しつつ，投入材料ごとに，サーマールリサイクル， マテリアルリサイクルへの適用を検討し，リサイクル可 能量(率)と処理量(重量・容量)の算出を行い, 現況との比 較を行った。

\section{（3）検討結果}

投入材料ごとに適切なリサイクルを推進することによ って,リサイクル量は現況の約 1.8 倍に増加し $(26,700 \mathrm{~kg}$ $\rightarrow 47,498 \mathrm{~kg})$, 処分量は重量比約 $40 \%(32,862 \mathrm{~kg} \rightarrow 12,243 \mathrm{~kg})$, 容量比約 $30 \%(29,528 \mathrm{~kg} \rightarrow 9,796 \mathrm{~kg})$ に削隇できることが確

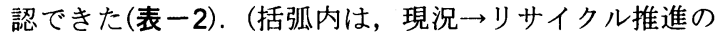
数值を示す) 
衰一3 代表的な紛争原因

\begin{tabular}{|c|c|}
\hline 要 因 & 代表的な紛争原因の例 \\
\hline $\begin{array}{l}\text { 環境污染への } \\
\text { 不安 }\end{array}$ & 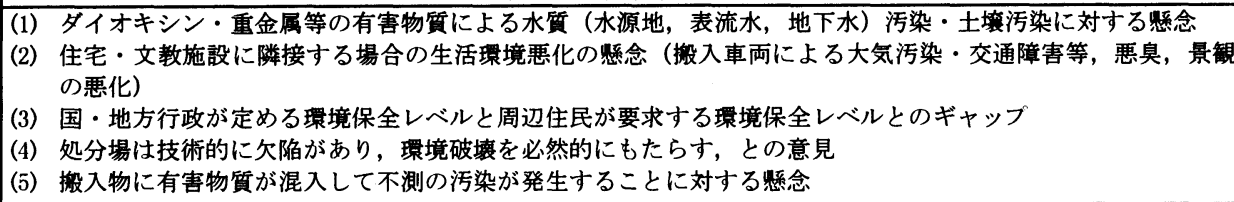 \\
\hline $\begin{array}{l}\text { 事業主体一の } \\
\text { 不信感 }\end{array}$ & 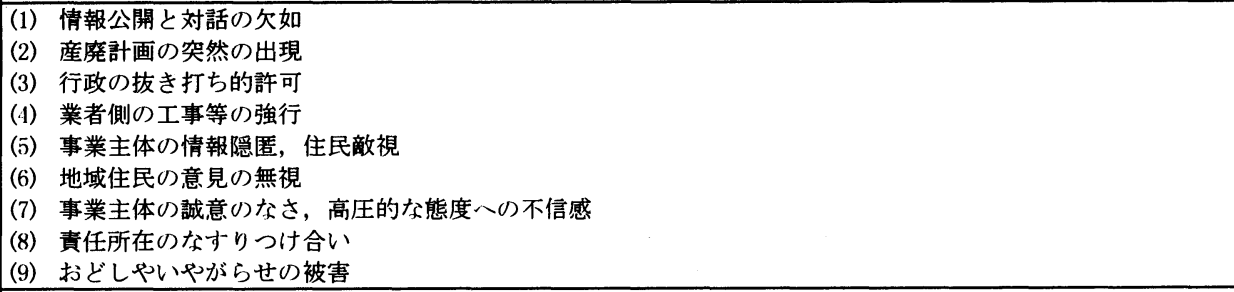 \\
\hline $\begin{array}{l}\text { 負担に対寸る } \\
\text { 不公平感 }\end{array}$ & $\begin{array}{l}\text { (1) 立地選定の根拠の不明確さ } \\
\text { (2) ごみの越境」処理への反対 } \\
\text { (3) 人口の少ない地域 (過疎の村等) への多量の廃棄物の集中 }\end{array}$ \\
\hline
\end{tabular}

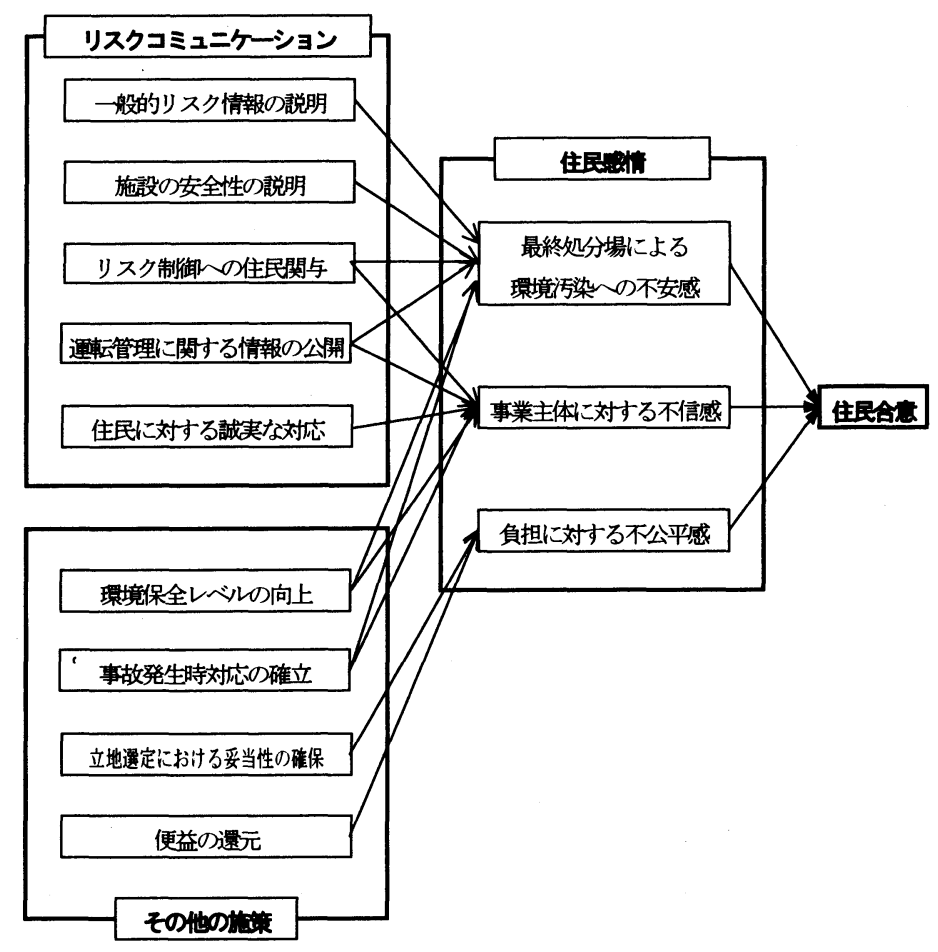

図-3 住民合意と住民感情, 住民感情へのアプローチ方策の要因関連図

\section{6. 紛争の原因と住民参加}

最終処分場の建設をめぐって，住民と事業主体（施設 設置事業者，行政）の間で多くの紛争が起きている．最 終処分場建設に対する紛争の原因と住民参加・合意形成 の方法等について文献，地方自治体の資料等を調查し， これらの調査結果に基づき住民合意形成の促進に向けた
視点を整理した.

廃棄物処理施設立地に対する紛争事例（住民投票等の 事(例), 及び紛争が回避された事例のそれぞれについて, 計画から建設までの手続き, 住民参加の時期や方法など について調査し, 紛争原因と紛争を回避する方策及び住 民合意形成の促進に向けた視点をまとめた. 


\section{（1）紛争の原因}

各地で発生している紛争の主な要因としては, (1)環境 污染への不安, (2)事業主体（施設設置事業者, 行政） の不信感, (3)負担に対する不公平感, の大きく 3 つが挙 げられた．代表的な紛争原因を表一3に示した。

\section{（2）合意形成促進に向けた視点}

住民合意を形成するためには，これら 3 つの要因にア プローチして「不安感」,「不信感」,「不公平感」を軽減 する観点から働きかけることが重要である.

合意形成に向けた視点として, 住民合意と住民感情, 住民感情へのアプローチ方策の要因関連について図ー3 に示した。アプローチの手法としては,「リスクコミュ ニケーション」によるものと，「その他施策」によるも のに大別される.

「リスクコミュニケーション」としては, 「日常生活 の中で一般人がどのようなリスクにさらされているか」 といった「一般的なリスク情報」の説明，また「施設の 安全性の説明」を通じて「不安感」の軽減を図ることが 挙げられる．また，施設の計画・運転管理への住民参加 等の「リスク制御への住民関与」や，モニタリング結果 の公表等の「運転管理に関する情報の公開」は，「不安 感」「不信感」の軽減を図る上で重要な手段と考えられ る，その他，「不信感」を軽減する上では「住民に対す る誠実な対応」が挙げられる

一方，「その他策」としては,「不安感」,「不信感」の 軽減を図るに当たって「施設の環境保全レベルの向上」,

「事故発生時対応の確立」が重要な視点と考えられる. 特 に，現在の技術レベルでは施設の安全性について住民側に 納得されずらい状況もあることから，フェイルセーフの仕 組みについて技術的，財政的に整備することが重要であろ う。また「不公平感」の軽減を図るに当たっては,「立地 選定における妥当性の確保」, 地域還元措置の実施等によ る「便益の還元」といったことも有効であろう．

紛争事例においては，様々な理由が複合的に作用して 住民の反対感情が増幅されるケースもあると考えられる. 周辺住民の「不安感」,「不信感」,「不公平感」といった 反対感情とその背景を十分に把握し，これらが緩和され るよう多面的にアプローチ寸ることが必要と考えられる. 上記アプローチ全てを実施することは現実的には不可能 と考えられるが，各事業主体の事情に合わせて可能な限 りこれらの措置を実施することが住民合意形成を図る上 で有効であろう。 なお, 平成 10 年度の廃棄物処理法改 正によって生活環境影響調查書の添付が義務づけられ，
その中で住民参加等が可能となるなど住民関与，情報公 開の取り組みが今後一定程度進むものと考えられるが, 事業主体は法定レベルの取り組みにとどまることなく， ISO14000 シリーズ取得等の自主的な取り組みを実施する など，住民との信頼関倸構築に向けて積極的に取り組む ことが今後さらに求められることになろう.

\section{7. ごみ処理の広域化における地域融和型廃棄物 計画}

廃棄物計画の構造分析，廃棄物管理施設の立地に関す る合意形成，そのための住民参加技法について検討した。 問題発見から跡地利用までトータルシステムにおける最 終処分場関連リスク認識度の構造モデルを作成し,さら に合意形成の程度を示す評価関数を設定して, KSIM 法 による数值シミュレーション的検討を行った．住民参加 の制度面に特化した事例研究として，スーパーファンド 法の CRP(Community Relation Plan)の事例, および流域開 発における環境保護手法として用いられている CBEP(Community Based Environmental Planning)の事例を, 関連する主体, 情報の授受およびその経時変化, 具体的 な技法, 情報のチャンネル, キーパースンの役割等に注 目して分析を行うとともに, この分析枠組に従い，日本 の事例の分析を行い，住民参加のプロセスや計画の策定 プロセスの相互比較を行った. 以上をふまえて，今後， 避けては通れないごみ処理の広域化における合意形成の 問題について事例整理ならびにそこで必要となる地域融 和型の計画について検討した，すなわち，事例の比較分 析を通じ，地域融和型廃棄物計画について，排出抑制， リサイクル促進, 中間処理, 最終処分における排出側と 最終処分側とが適切に負担を分担しあうシステムの構築 に焦点を当てる.

図-4に各課題の位置づけ，研究の観点を示す．また， 合意形成に視点を当てたときの研究課題の相互関係を図 -5 に示した.

\section{8. 海面埋立処分場における浸出水及び余水の性 状予測と制御}

\section{（1）廃棄物の最終処分場と海面埋立}

廃棄物最終処分場容量の枯渴は，わが国社会の媣刻な 問題となっている．その理由としては，これまで処分場 が設けられてきた山間部に適地が少なくなったこと，さ らには用地取得のための住民合意を得ることが困難にな 


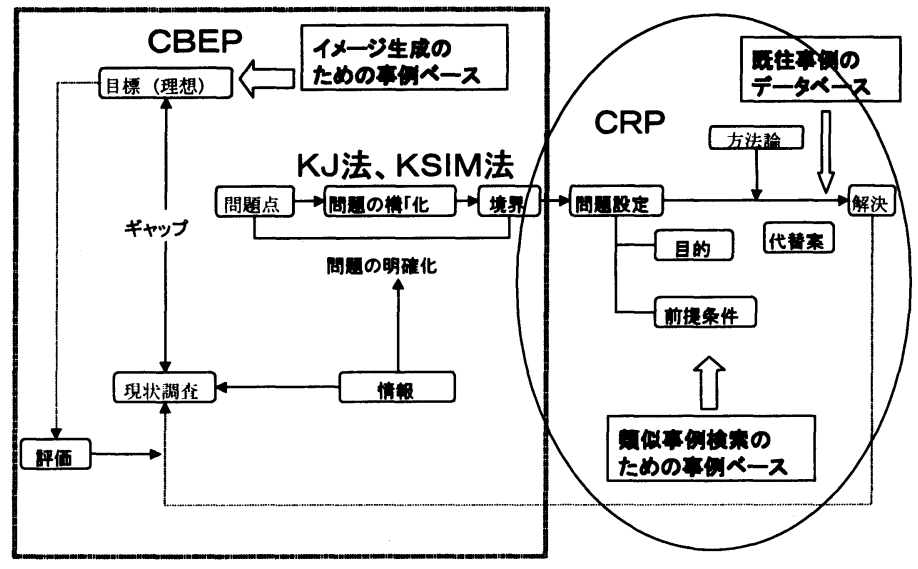

図-4 廃衰物計画における課題と研究の観点

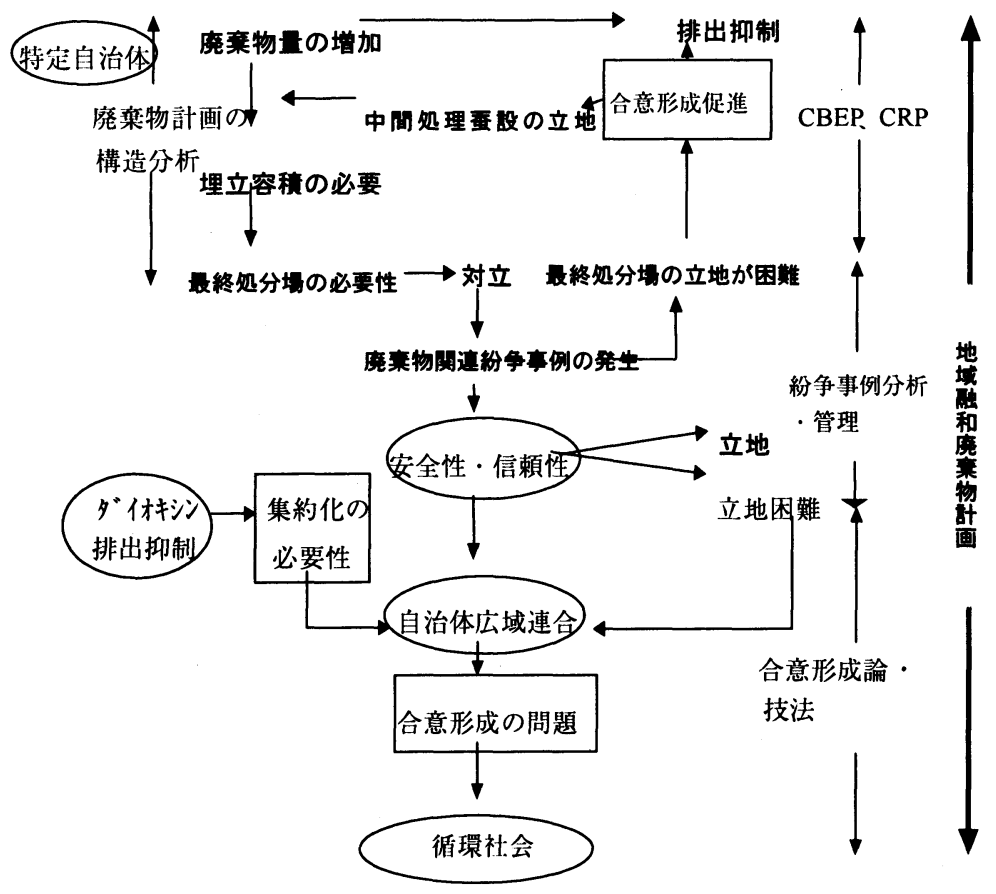

図-5 研究課題の相互関係

ってきていることなどがあげられる．これらを背景に， 海面を部分的に仕切り，そこを埋立地とする海面埋立処 分場の建設が各地で見られるようにきている.

最終処分場の用地取得のための合意形成が困難となっ ている大きな要因は, 廃棄物の埋立処分に対する住民の 不安であり, それを生じさせている原因の主要なものの 一つが浸出水(埋立廃棄物層を通過した後の雨水)による 周辺環境の污染に対する危惧である. 海面埋立の場合は, 利害関係にある住民が比較的少なく，また広域処分に対
応できる大容量の用地確保が可能であり, 新しい国土創 出が図れるという利点もあることに加えて, この浸出水 による污染の危険性(リスク)も低減されると予想されて いる. しかしながら，これまでの海面埋立処分場の建設 例を見ると，その理由として，「陸上部に適地がない」 ことが多くの場合あげられており，山間埋立に対して海 面埋立の低リスクが十分明らかにされた上で，その建設 の推進が図られているとは言い難いのも現状である.

本研究は, 海面埋立におけるこのような浸出水のリス 
衰-4 廃亲物の陸上埋立と海面埋立のリスク比較

\begin{tabular}{|c|c|c|c|c|c|}
\hline 用地 & 重金属 & 窒素 & 塩類 & THMFP & 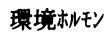 \\
\hline 山間 & $\triangle$ & $\triangle$ & $\times x$ & $\times$ & $?$ \\
\hline 海面 & $?$ & $\triangle$ & 0 & 0 & $?$ \\
\hline \multicolumn{6}{|c|}{ ○：リスクなし } \\
\hline \multicolumn{6}{|c|}{$\triangle$ ：ややリスクあり } \\
\hline \multicolumn{6}{|c|}{ × ： リスクあり } \\
\hline \multicolumn{6}{|c|}{ ×× ： 大きなリスクあり } \\
\hline
\end{tabular}

クについて検討することを通して，山間埋立に対する海 面埋立の優位性を明らかにしようとするものである.

\section{（2）最終処分場における浸出水のリスク}

埋立廃棄物および浸出水の有するリスクに関して, 含 有される可能性のある污濁物質等で定性的に整理し, 山 間埋立と海面埋立とを比較したものが表ー4である.

トリハロメタン生成能(THMFP)は, 水道水源での塩素 消毒の際に発現するため, 海面埋立でのリスクはないと 判断できる. また, 近年の焼却残渣主体の埋立によって 生じている浸出水中の塩類の高港度化は, 放流先の河川 等陸水域の生態系を大きく変化させる可能性があり, 山 間埋立ではリスクを有するが, 周囲が海水である海面埋 立でのリスクは小さいと考えられる.

一般に海面埋立処分場の場合, 埋め立て開始時に海水 が内水として存在する. 埋立の経過と降雨により, この 内水は排除される必要が生じ, これを余水と呼ぶ. 従来 から処分場の有するリスクとして大きな関心が払われて きた重金属類の溶出は, 海面埋立の場合, 廃牽物層と雨 水および内水である海水との接触, さらに焼却残渣が含 まれる場合はそれからの塩類等の洗い出しという極めて 複雑な環境にさらされて発現することになる.そのため, この余水での性状の予測が困難な課題となっている.

\section{（3）埋立魔亲物からの重金属の溶出に関する検討}

本研究では, 都市清掃工場の焼却残渣を試料として, 環境庁告示 13 号による振とう溶出試験に加え, カラム 式循環溶出実験を実施し，各種環境下での重金属の溶出 挙動について検討を行っている.

図一6，7 は，キレート棛により重金属の不溶化処理し た電気集痤灰(処理 EP 灰)と末処理の EP 灰をそれぞれ試 料としたカラム実験の結果を $\mathrm{Pb}$ について示したもので ある．本実験では，カラム内の灰試料に純水あるいは人 工海水を循環させて, 浱度変化を測定しているが, 未処 理 EP 灰に対して，キレート処理された EP 灰で $\mathrm{Pb}$ の溶

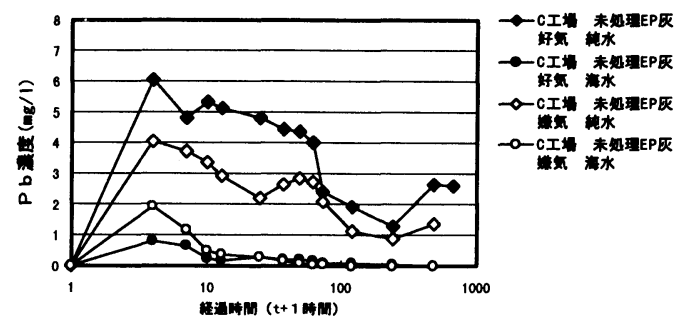

図-6 循環水中の $\mathrm{Pb}$ 洤度の経時変化(未処理 $\mathrm{EP}$ 灰)

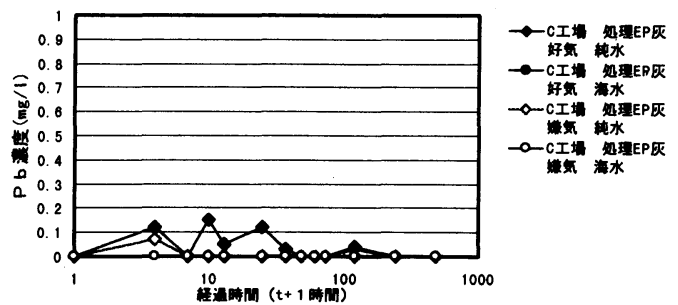

图-7 循環水中の $\mathrm{Pb}$ 潾度の経時変化(処理 $\mathrm{EP}$ 灰)

出が明らかに抑制されているのがわかる．また，末処理 $\mathrm{EP}$ 灰からの溶出も純水中での高い值に比較して, 海水中 では明らかな抑制が認められるとともに，純水よりも早 く低減する傾向が確認された。 したがって，仮に予期せ ぬ原因によって埋立廃棄物からの $\mathrm{Pb}$ の漏出が生じた場 合でも, 山間埋立での地下水など淡水への影響と比較し て，周囲が海水である海面埋立の方がリスクが小さいと 判断される.

\section{9. 海面埋立工法と早期安定化}

\section{（1）糜止基萑と早期安定化}

日本では，数は少ないが大規模海面埋立処分場におけ る処分が進んでおり, 今後, 海面埋立が增えてくること が予想される. その埋立完了後の跡地利用も大きな期待 が寄せられている．ところが，以前は埋立完了・閉鎖に ついては，基準が明らかではなかった，そこで，共同命 令 (平成 10 年 6 月) により最終処分場の廃止基淮が設 定された. 廃止基淮には, 保有水等の水質が 2 年以上に わたり排水基準等に適合していると認められることが基 準の一つとして記されている，海面埋立処分場における 水処理施設一の集水は, 内水の表層部で行われることが 多い. 内水の表層部が排水基隻等に適合していても, 哚 層部（又は廃棄物層内間隙水）では排水基淮等に適合し ていない場合がある．現在のところ廃止基隻の適用につ いて，検討が行われているところであるが，埋立地の安 定化としては, 埋立地深層部の間隙水の性状も内水表層 
部と同等に改善されることが重要であると考える.

本研究では, 埋立地内部の早期安定化を目指して, 栄 養塩類（窒素，炭素等）の分解を促し，併せて重金属類 等の有害物質の洗浄を促進して，埋立完了後に周辺環境 へ与える影響を出来るだけ削減するための新たな埋立工 法の開発を目的としている.

\section{（2）新たな埋立工法の概念}

廃棄物に含まれる污濁成分は, 廃棄物層中の間隙水が 留まっている状態（静置状態）よりも，埋立廃棄物層内 の間隙水が移動した方が，間隙水中により多くの污濁成 分を溶出することができると考えられる．また，循環に 伴い, 大気中の酸素, 二酸化炭素との接触による廃棄物 層内での污濁成分浄化の可能性も考えられる。ここで提 案する工法の概念を示す. 埋め立てられた廃棄物地盤に は一定間隔で集水井戸を設け，井戸の中には，集められ てくる間隙水を揚水，排水できるように，ポンプを設置 する．埋立廃書物中に短絡流が生じると，廃棄物全体の 洗い出し効果が期待できなくなるため, 本工法では内水 位と井戸内の水位の水頭差によって緩慢に間隙水を集水 する. 集水した間隙水は内水部にポンプ压送し, 循環を 行う。 また，この内水を処理した後，外海に排水する.

本工法は，循環により埋立廃棄物中に含まれる污濁物 質が溶出した内水を, 廃棄物中あるいは内水中での吸着, 生物分解による浄化, 安定化させることを狙いとしてい る. 本研究では, 間隙水の流動によって, どの程度の吸 着, 生物分解が起きるのかを詳細に調べることを目的と している.このための実験は, 海面埋立地内を模擬した 実験模型槽により循環浄化の効果を調べた.

\section{（3）実験方法}

3 条件での循環実験を行っているが，ここでは RUN1 のみの結果を示す，実験装置を図一8に示す. 実験装置 は, カラムと貯水槽, ヘッドタンクからなっている. カ ラムは，内径 $500 \mathrm{~mm}$ ，長さ $2000 \mathrm{~mm}$ の円筒形をしている. RUN1 の貯水槽には摚拌機が取り付けられている。この 実験装置で海水循環をおこなった。実験に用いた試料は， 一般廃棄物の焼却灰を使用した。

RUN1 では，提案した工法を想定し，廃棄物層から流 出した浸透水を貯水槽で長い時間滞留させる条件で実験 を行った．充填した焼却灰重量は $522.6 \mathrm{~kg}$ であった。使 用水量はカラム内で $123 \mathrm{~L}$ ，カラム外で $110 \mathrm{~L}$ である。透 水係数は, 約 $10^{\mathrm{t}} \mathrm{cm} / \mathrm{s}$ となった。本実験では, ヘッドタ ンクより採水した流入水, 廃棄物充填カラムを通水した

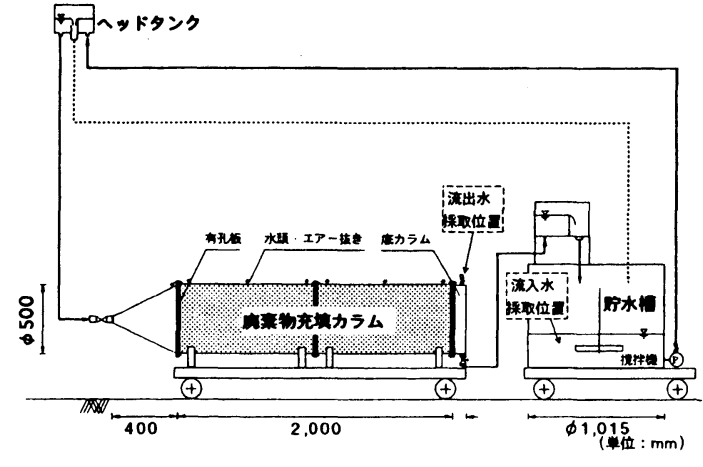

図一8 カラム実験装置 (RUN1)

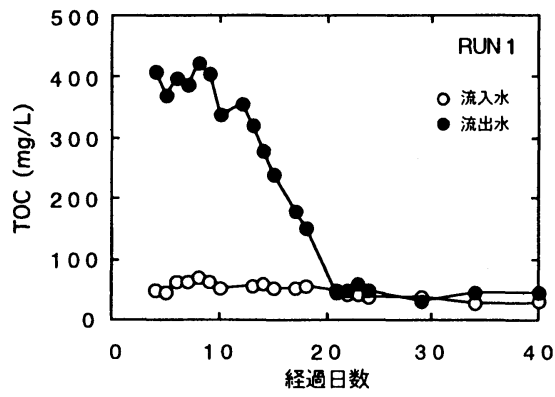

図-9 T()C U)経日変化

間隙水（流入水）を底カラム上部のコックより採水し分 析を行った. 実験では, $\mathrm{pH}, \mathrm{ORP}, \mathrm{BOD}, \mathrm{COD}_{\mathrm{Mln}}, \mathrm{TOC}$, $\mathrm{T}-\mathrm{N} ，$ 有害重金属などの測定を行った.

\section{（4）結果及び考察}

有機污濁成分の指標として TOC, T-N について検討し た. TOC 浱度の経日変化を図一9に示す．測定初期には, 流入水 $\mathrm{TOC}$ 濃度が $50 \mathrm{mg} / \mathrm{L}$ 前後であるのに対し, 流出水 $\mathrm{TOC}$ 漘度は $400 \mathrm{mg} / \mathrm{L}$ 前後と大きく污濁成分の溶出が認 められ，その海水が貯水槽，ヘッドタンクを循環するこ とにより，TOC 濃度が $50 \mathrm{mg} / \mathrm{L}$ 程度まで低減した。そその 後, 流出水 TOC 濃度は 10 日目あたりから大きく減少し, 20 日目前後には流入水の TOC 濃度とほぼ同程度となっ ている. さらに, 20 日目以降の流入水, 流出水の TOC 濃度はほぼ一定值となった。流出水の $\mathrm{T}-\mathrm{N}$ 濃度は，TOC 同様に，測定初期から低下しており，実験開始から約 35 日前後で流入水の $\mathrm{T}-\mathrm{N}$ 濃度と同程度となった。

このように，循環により，廃棄物間隙水中の有機污濁 成分の早期減少が認められた。このことは，提案を行っ た埋立工法による，廃棄物層内間隙水および内水の循環 浄化の可能性が確認されたといえる．なお，有機污濁成 分の除去機構については，大きく，カルシウム化合物の 沈殿生成に伴う除去と微生物による分解が推測される。 
衰-5 立地〜閉鎖における海面埋立処分場と陸上埋立処分場の比較

\begin{tabular}{|c|c|c|c|}
\hline & & 陸上埋立 & 海面埋立 \\
\hline (1) 立地 & $\begin{array}{l}\text { 埸所の数 } \\
\text { 選定の容易性 }\end{array}$ & 場所的には多くの可能性がある & \begin{tabular}{|l} 
選定できる場所が限定される \\
陸上埋立に比べて制約条件が少ない
\end{tabular} \\
\hline （2）計画・調整 & $\begin{array}{l}\text { 国レベル } \\
\text { 地域レベル }\end{array}$ & 比較的容易 & 省庁間調整が比校的困難 \\
\hline (3) 規模 & & 小 & 大 \\
\hline （4）経済性 & & $\begin{array}{l}\text { 用地確保費用が莫大 } \\
\text { 跡地利用の経済効果が低い }\end{array}$ & $\begin{array}{l}\text { スケールメリット } \\
\text { 規模が大きいので，初期投資が莫大 } \\
\text { 新たな闻士㓱造による経済効果が期待 }\end{array}$ \\
\hline （5）輸送（交通） & $\begin{array}{l}\text { 公域輸送 } \\
\text { 船舶榆送 }\end{array}$ & 㕕域あり & $\begin{array}{l}\text { 㕕域輸送 } \\
\text { 船船輸送 }\end{array}$ \\
\hline (6) 鹿菓物フロー- & & 部市一地方 & 地方一.都市洞边 \\
\hline （7）処分詓ひ確保 & 每期的確保 & 知期的確保デあり、確保に不文 & 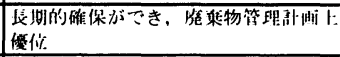 \\
\hline (8) 受人れ & 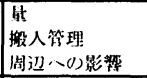 & $\begin{array}{l}\text { 般人施少 } \\
\text { やや怵難 } \\
\text { やや゙あり }\end{array}$ & 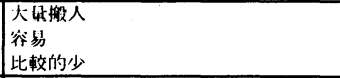 \\
\hline （9）作業環境 & 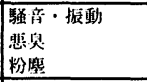 & $\begin{array}{c}\text { 注意が必要 } \\
n \\
n \\
\end{array}$ & $\begin{array}{l}\text { 比較的少 } \\
\quad " \\
\text { 强風注意 }\end{array}$ \\
\hline (10)水道水源污染 & & 注意方必要 & リスクなし \\
\hline (11)洮出水の処理 & 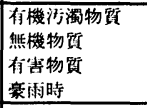 & \begin{tabular}{|l} 
比較的容易 \\
塩除去ひ必要性 \\
汪とルどなし \\
弱点あり \\
\end{tabular} & $\begin{array}{l}\text { 比校的产易 } \\
\text { 必要性なし } \\
\text { ほ上ルどなし } \\
\text { 内水池が大きく、問題なし } \\
\end{array}$ \\
\hline (12)放流先 & & $\begin{array}{l}\text { 河川・湖 } \\
\text { 下水道放流 } \\
\text { 無法流あり } \\
\end{array}$ & $\begin{array}{l}\text { 海域 } \\
\text { 下水道放流 }\end{array}$ \\
\hline (13)埋立期間 & & \begin{tabular}{|l|l|} 
知期～長期 \\
\end{tabular} & 長期 \\
\hline (14)安定化 & & 比較的短い & 比較的長い \\
\hline (15)跡地利用 & & 緑地・公園に限定 & T:業団地等比較的多様性あり \\
\hline (16)リスクポテンシャル & $\begin{array}{l}\text { 保有水の移動性 } \\
\text { しゃ水障害 } \\
\text { 埋立廃辑物 }\end{array}$ & $\begin{array}{l}\text { 垂淔方向の移動性大 } \\
\text { 地形的不連続部に弱点 -*しゃ水面の } \\
\text { 水压負荷削除で対芯 } \\
\text { 分散化 } \rightarrow \text { 管理能力低下の恐れ } \\
\end{array}$ & $\begin{array}{l}\text { 動水幻配が小一移動性低い } \\
\text { 護岸しゃ水の優秀な技術者の㕍用可能 }\end{array}$ \\
\hline (17)災害対策 & $\begin{array}{l}\text { 地震 } \\
\text { 波浪・淇水 } \\
\text { 谕送・搬入 }\end{array}$ & $\begin{array}{l}\text { しゃ水工部に耐震を考缯 } \\
\text { 設計で考虑 } \\
\text { 蝓送ルートの破埭への対処 }\end{array}$ & 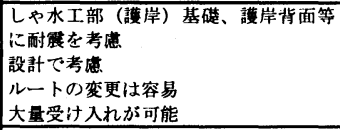 \\
\hline (18)国土創造 & & 少ない & 新たな大地の創出 \\
\hline (19)環境創造 & & 緑地・公固等の環境創造 & $\begin{array}{l}\text { 大規模改変のために新たな骤境創造事 } \\
\text { 㡀が必要 }\end{array}$ \\
\hline (20)住民合意 & & $\begin{array}{l}\text { 地権者が多い、水利権調擎、安全性に } \\
\text { 対する不安等住民合意が困難 }\end{array}$ & $\begin{array}{l}\text { 水面権利者、漁業権者等の利害関係者 } \\
\text { との調整が必要。 }\end{array}$ \\
\hline
\end{tabular}

\section{0. 広域最終埋立処分場における跡地利用の検討}

我が国においては，国民生活が豊かになるのに比例し て廃棄物量は增大し続けている. また, 廃棄物の質は時 代とともに変化し, 適正処理が困難なものの量も增加し てきた。こうした廃棄物の最終処分場の建設には，環境 保全を目的として廃棄物の性状に応じた立地基準が定め られており, 最終処分場の種類は, 構造面から「安定型」 「管理型」「遮断型」に分類されている. 一方, 大都市 部での土地需要は根強いものがあり, その一環として埋 立処分場が利用土地対象とされ, 跡地をどのように利用 するかが大きな検討課題となっている.

従来から進めてきた広域最終埋立処分場における跡地 利用に関しての検討内容は以下の通りである.

- 大規模埋め立て技術とその評価

・ 跡地利用における問題点 一 地盤物性

不均質地盤物性の推定方法
- 跡地利用に関する一般的な問題

・ 地盤調查と問題に対する対策方法

・廃棄物の影響 一管理と対策

- 跡地利用に向けての新しい取り組み

整理すると, 跡地利用に関して最も問題となるのは, 地盤特性, 浸出水, 発生ガスの 3 点に絞られると考えら れる.

実用的に跡地利用する場合の問題を抽出すると，不同 沈下, 構造物の設置, ガス発生や悪臭, 污染, 耐用年数, 樹木の育成, 杭構造物の設置, 土壤の酾成・安定化など がある.地盤の改良や廃棄物の封じ込めなど新しい方法 を用いて跡地を利用しやすい土地にする必要があるが， 社会情勢の変化から, 従来のような画一的な跡地利用は 望めなくなっており，跡地の高度利用に向けて付加価値 を高める方策を探らなければならない状況である。

- 最終処分場の性能評価 


\section{1. 環境保全型海面埋立処分について}

循環型社会一持続可能な社会は 21 世紀の極めて重要 な課題である，循環型社会の形成には今までとられてき た一過型の消費経済から循環型経済への転換が必要であ り，そのための技術開発やシステム構築が極めて重要で ある.そのような状況の中，例えば科学技術政策におい てゼロエミッションシステム構築等のキーワードが示す ように，再利用技術やシステムが大きな関心を呼んでい る.

廃棄物埋立処分場の根本的な解決のためには，20〜 50 年，場合によっては 100 年というスケールの環境保全型 大規模海面埋立処分場を廃棄物が集中的に発生している 大都市圈の海域に建設することを提案し, その効果や影 響を議論, 評価しておく必要がある. そこで, 海面埋立 処分を促進する上での現状と問題点を表一5に示す.こ の表では基本的には, 環境保全型海面埋立処分に関する 立地問題と環境影響を中心に評価した。

一方, 環境保全型海面埋立処分を進めるに当たっては, 環境保全, 污染防止, 防災等に関する研究開発が必要と なろう。その主なものは，以下のようなものが挙げられ る.

（1）陸水と海水による溶出特性

(2) 海洋污染防止技術

（3）大規模埋立技術

(4) 配置計画

（5）海面埋立の LCA（陸上埋立処分との比較）

12. おわりに

廃棄物の最終処分場, 特に海面埋立処分場について平 成 9〜11 年度の 3 年間に渡って行ってきた議論を取りま
とめたものを紹介した.

廃棄物の処理において, 必要な埋立処分場の確保が極 めて難しくなってきている，しかしながら，一方で飛行 場の建設等の海面埋立は今後も引き続き行われるものと 考えられ，埋立材の需要はあると推定される. 埋立処分 される必要のある廃棄物がある一方で，埋立材の需要が あるので環境保全上問題のない海面埋立ができれば一石 二鳥の解決策となる.

ただし，これまでの最終処分場には様々な物性の廃棄 物が混在した状態で搬入されており，処分場跡地の地盤 の安定性の点で問題を抱えている場合が数多く見られる. 今後は最終処分場の跡地利用についても十分に配慮し, 例えば廃棄物の中間処理による埋立廃棄物の品質改善等 についても考えていく必要があろう。 その他, 色々と検 討すべき課題は多いが，このような問題が土木学会の中 で多くの関係者の参加の下に議論されたのは有益であっ た. 今後も引き続き, 最終処分場についての環境保全, 特に環境影響とその評価について検討すべきと考える.

\section{参考文献}

（文責 : 田中 勝）

1) (社)土木学会: 平成 10 年度広域最終処分場計画調查 廃棄 物海面埋立環境保全調查報告書, 1999 .

2) 田中 勝: 埋立処分量最小化一の戦略一IIPR と容器包装リサ イクル法一, INDUST, Vol.15, No.3, pp.11-15. 20()0.

(2000. 3. 9 受付) 